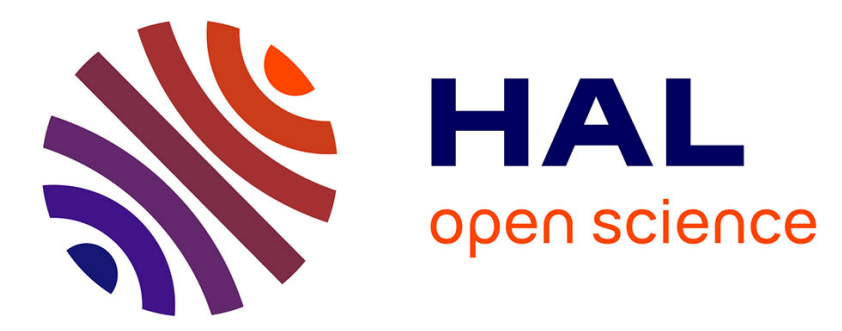

\title{
SAXS on invertebrate dioxygen carriers
}

\author{
Michel Beltramini, E. Borghi, P. Di Muro, A. Ghiretti Magaldi, A. La
}

Monaca, B. Salvato, C. Santini, G. Tognon

\section{To cite this version:}

Michel Beltramini, E. Borghi, P. Di Muro, A. Ghiretti Magaldi, A. La Monaca, et al.. SAXS on invertebrate dioxygen carriers. Journal de Physique IV Proceedings, 1993, 03 (C8), pp.C8-249-C8252. 10.1051/jp4:1993848. jpa-00252279

\section{HAL Id: jpa-00252279 https://hal.science/jpa-00252279}

Submitted on 1 Jan 1993

HAL is a multi-disciplinary open access archive for the deposit and dissemination of scientific research documents, whether they are published or not. The documents may come from teaching and research institutions in France or abroad, or from public or private research centers.
L'archive ouverte pluridisciplinaire HAL, est destinée au dépôt et à la diffusion de documents scientifiques de niveau recherche, publiés ou non, émanant des établissements d'enseignement et de recherche français ou étrangers, des laboratoires publics ou privés. 


\title{
SAXS on invertebrate dioxygen carriers
}

\author{
M. BELTRAMINI ${ }^{* * *}$, E. BORGHI***, P. DI MURO ${ }^{*}$, A. GHIRETTI MAGALDI ${ }^{* * * *}$, \\ A. LA MONACA ${ }^{* * * *}$, B. SALVATO ${ }^{* * *}$, C. SANTINI $^{*}$ and G. TOGNON ${ }^{* *}$ \\ * Dipartimento di Biologia, Università di Padova, Via Trieste 75, 35121 Padova, Italy \\ ** Centro CNR Emocianine ed altre Metallo-Proteine, Via Trieste 75, 35121 Padova, Italy \\ *** Dipartimento di Chimica, Università "La Sapienza"-Roma, 00195 Roma, Italy \\ **** INFN, Laboratori Nazionali di Frascati, P.O. Box 13, 00044 Frascati, Italy
}

\begin{abstract}
Some preliminary SAXS measurements have been carried out on four different extracellular invertebrate dioxygen carriers. The validity of the procedure has been tested on arthropod hemocyanin: the radii of gyration deduced from SAXS spectra agree with those calculated from the dimensions of the structure determined by X-ray crystallography. The radii of gyration of Spirographis spallanzanii chlorocruorin agrees with values deduced from 3D structures obtained with Electron Microscopy. The radius of gyration and the radius of gyration of the cross section of Octopus vulgaris hemocyanin are compatible with a ring structure, as deduced from investigations made by Electron Microscopy.
\end{abstract}

\section{Introduction}

The tools which can be used in the definition of the quaternary structure of oligomeric proteins are mainly X-ray scattering methods and Transmission Electron Microscopy with computerized 3D reconstruction techniques based on the projection theorem of Fourier transform.

In the case of difficult crystallization, Conventional Transmission Electron Microscopy with Negative Stain (CTEM) can be used with single particles methods, which allow a resolution of $20 \div 30 \AA$, so that small species as well as subunits are not suited for this technique; furthermore CTEM gives an adequate picture of the internal organization of molecular aggregates only for particles of high surface/volume ratio while, in the other cases, essentially a surface description, with poor information concerning internal mass distribution is obtained. Finally, flattening and other distortion effects during the sample preparation and the observation may affect the quality of the results.

In this work we have addressed the problem of the quaternary organization of invertebrate dioxygen carriers, hemocyanins and chlorocruorin by a combination of Synchrotron Radiation Small Angle X-ray Scattering (SAXS) and CTEM. Hemocyanins from Carcinus maenas, Cancer pagurus (Arthopoda, crustacea), Octopus vulgaris (Mollusca, octopoda) and the chlorocruorin from Spirographis spallanzanii (Annelida, policheta) have been preliminarily studied. All these proteins in the native state are extracellular oligomeric species, whose molecular weight ranges between $4.5 \times 10^{5}$ and $3 \times 10^{6} \mathrm{Da}$, and can be dissociated at relatively high $\mathrm{pH}$ (9-9.5) in the absence of divalent cations to yield subunits.

The aim of our research is to describe with SAXS the dissociation products of such proteins as weil as the correlation between subunits and the whole molecules.

\section{Material and Methods}

Hemocyanins were isolated according to [1]. Spirographis s. chlorocruorin was extracted and purified as described by [2].

The proteins, stored at $-20^{\circ} \mathrm{C}$ in Tris- $\mathrm{HCl} 50 \mathrm{mM} \mathrm{CaCl} 20 \mathrm{mM}$ in $20 \%$ sucrose, were thawed and diluted in appropiate buffers just immediatly before the measurements.

Dissociated samples were obtained by dissolving aliquots of protein stock solutions in Tris-propionate 
$50 \mathrm{nM}$, isopropanol $0.2 \mathrm{M}$, EDTA $10 \mathrm{mM}$ pH 9.2 for Octopus $v$. hemocyanin and in Tris/propionate $50 \mathrm{mM}$, isopropanol $0.2 \mathrm{M}$, EDTA $10 \mathrm{mM}$, urea $2 \mathrm{M} \mathrm{pH} 9.2$ for Carcinus $m$. and Cancer $p$. hemosyanins. Spirographis s. chlorocruorin, was dissociated with Tris- $\mathrm{HCl} 50 \mathrm{mM}$ pH 9 EDTA $10 \mathrm{mM}$. The measurements on $24 \mathrm{~S}$ and $16 \mathrm{~S}$ hemocyanins of Carcinus $\mathrm{m}$. were performed by diluting the protein in Tris/propionate, $50 \mathrm{mM}$ isopropanol $0.2 \mathrm{M} \mathrm{CaCl}_{2} 20 \mathrm{mM} \mathrm{pH} 7.0$ or in Tris/propionate $50 \mathrm{mM}$ isopropanol $0.2 \mathrm{M}$ EDTA $10 \mathrm{mM}$ pH 8.

The experiments were performed on the D24 SAXS station of LURE facility (Orsay, France). The sample solutions were irradiated with monocromatic radiation of $\lambda=1.608 \AA\left(\Delta \lambda \lambda=10^{-3}\right)$ with a recording time $\Delta t=400 \mathrm{sec}$. The scattered intensities were recorded on a position sensitive proportional detector, $1205 \mathrm{~mm}$ far from the sample, which allowed an angular resolution $\Delta s=1.192 \times 10-\AA^{-1}$ $(s=2 \sin (\theta) / \lambda)$. To collect the data, the program OTOKA from EMBL (Hamburg and Heidelberg) [3] was used. The scattering data were normalized and subjected to background subtraction. For every protein species several solutions, with concentrations ranging from $2 \mathrm{mg} / \mathrm{ml}$ to $13 \mathrm{mg} / \mathrm{ml}$ were examined.

$X$-ray scattering data were analyzed by using the Guinier approximation [4]. From the slope of the Guinier plots, obtained at various protein concentration from the linear portions of the scattering curves, the radii of gyration $\mathrm{Rg}$ were determined and extrapolated to zero protein concentration.
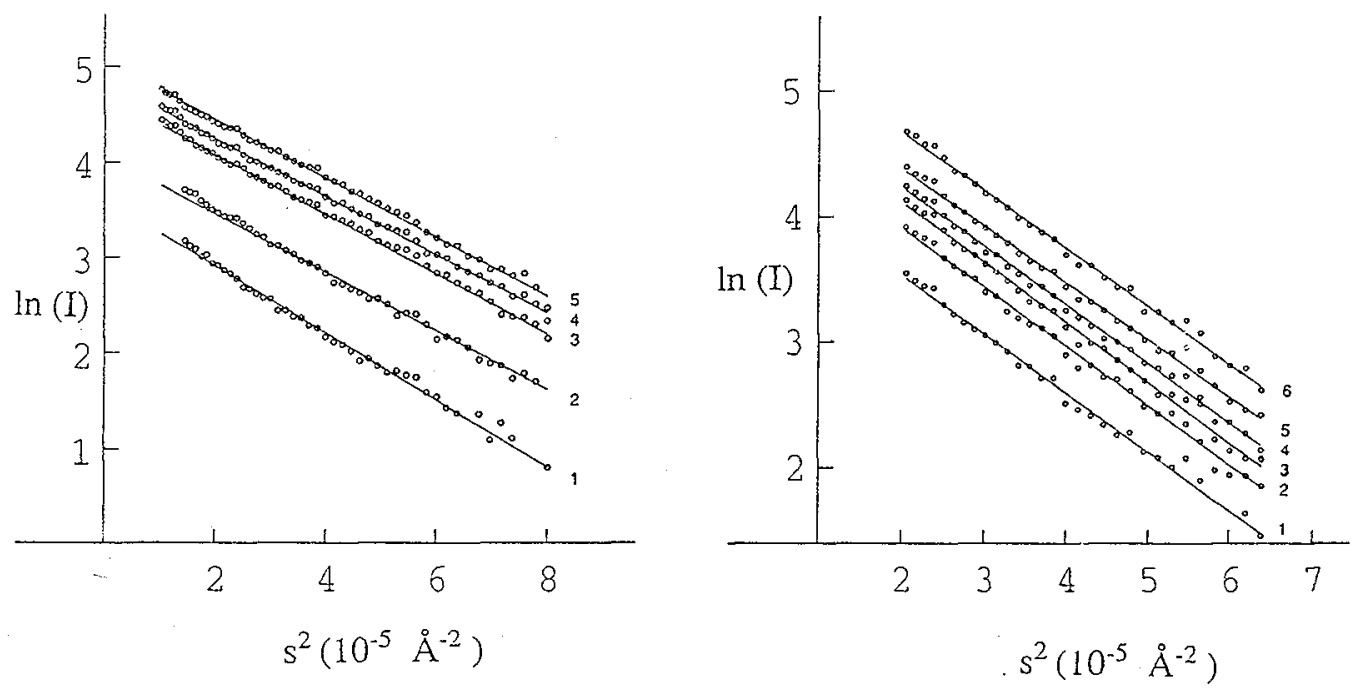

Fig.1 Left: Guinier plots of Spirographis s. chlorocruorin (protein concentrations in $\mathrm{mg} / \mathrm{ml}$ : 1 (Curve 1), $3.4(2), 6(3), 8.5(4), 10.2(5)$ ) after buffer subtraction. Right: Guiner plots of Octopus $v$. hemocyanin (protein concentrations $2.8(1), 4.7(2), 6.2(3), 8.75(4), 10.1(5), 14(6)$ ) after buffer subtraction.

\section{Results}

\subsection{Spirographis spallanzanii chlorocruorin}

A micrograph of this protein shows that it is a two tiered hexagonal disk [6]. It is thought to be made of up to 200 globin chains, organized hierarchically in tetramers, then in main subunits and finally in whole molecules, whose molecular weight is about $3 \mathrm{MDa}$. We examined a solution of the main subunit of Spirographis $s$. chlorocruorin with SAXS, and deduced two radii of gyration: $\mathrm{R}_{\mathrm{g} 2}=50 \AA$ corresponds to the main subunit and $\mathrm{R}_{\mathrm{g} 1}=23.3 \AA$, which probably refers to a lower weight dissociation product.

Using a 3D density map of such protein, obtained with CTEM and the Random Conical Tilting procedure [5][6], we calculated the radius of gyration, $\mathrm{Rg}=46 \AA$, of the main subunit. This value is slightly lower than that deduced by SAXS probably because of flattening during CTEM preparation and observation [4][5]. From a 3D density map of the whole molecule we also deduced a radius of gyration of 
$114 \AA$, which compares with the values $118 \AA$ and $120 \AA$ obtained with SAXS on the phylogenetically related erythrocruorin of Glossoscolex paulistus and Arenicola marina [8].

\subsection{Octopus vulgaris hemocyanin}

CTEM shows that this molluscan dioxygen carrier is roughly a cylinder, with diameter of $350 \AA$ and height of $170 \AA$ [9]: as commonly found in molluscan hemocyanins it possesses pentameric symmetry. We performed SAXS measurements on the 11S subunit obtained by dissociation [10], which has molecular weight of $250 \mathrm{kDa}$. Such a subunit shows a radius of gyration $\mathrm{Rg}=61 \AA$, and a radius of cross section $\mathrm{Rc}=42.7 \AA$ : a structure consisting of a ring with external diameter $90 \AA$ and internal diameter $80 \AA$ is compatible with these dimension. These latter values are subject to errors owing to the use of the invariant $Q$ of the theory [3]: within such errors we can say that there is agreement with the maximum dimension of $113 \AA$ found previously [11].

\subsection{Arthropod hemocyanins}

$X$-ray crystallography, CTEM and analytical untracentrifugation have shown that these proteins in $16 \mathrm{~S}$ aggregation state $(\mathrm{MW}=450 \mathrm{kDa})$ are built up by six equivalent subunits $(5 \mathrm{~S}, \mathrm{MW}=75 \mathrm{kDa})$ arranged in a trigonal antiprism. With both Carcinus $m$. and Cancer $p$. hemocyanins the $5 S$ subunits exhibit $R_{g}=29 \AA$. The hexameric $16 \mathrm{~S}$ species of Carcinus $m$. has $\mathrm{R}_{\mathrm{g}}=54 \AA$; at $\mathrm{pH}$ around neutrality and in the presence of $\mathrm{Ca}^{2+}, \mathrm{R}_{\mathrm{g}}=65.4 \AA$ is found, attributable to a species resulting from the association of two $16 \mathrm{~S}$ species $(24 \mathrm{~S}, \mathrm{Mw}=900 \mathrm{kDa})$, namely the double hexameric form. The values of the radii of gyration are in agreement with the dimensions deduced from X-ray crystallography on Panulirus interruptus hemocyanin [12] [13].

Table 1. SAXS parameters of invertebrate dioxygen carriers, extrapolated to infinite dilution.

\begin{tabular}{|c|c|c|c|}
\hline Protein sample & $\operatorname{Rg}(\AA)$ & $\operatorname{Rc}(\AA)$ & $\begin{array}{l}\operatorname{Rg}(\AA) \\
\text { (models) }\end{array}$ \\
\hline $\begin{array}{l}\text { A. marina eritrocruorin } \\
\text { (whole protein) }\end{array}$ & $120^{f}$ & & \\
\hline $\begin{array}{c}\text { G. paulistus. eritrocruorin } \\
\text { (whole protein) }\end{array}$ & $118^{f}$ & & \\
\hline $\begin{array}{l}\text { S. spallanzanii chlorocruorin } \\
\text { (whole protein) }\end{array}$ & & & 114 \\
\hline $\begin{array}{c}\text { S. spallanzanii } \\
\text { chlorocruorin } 11 \mathrm{~S}\end{array}$ & $\begin{array}{r}50 \\
23.3^{*} \\
\end{array}$ & . & 46 \\
\hline $\begin{array}{l}\text { Octopus vulgaris } \\
\text { 11S hemocyanin }\end{array}$ & 61 & 42.7 & \\
\hline $\begin{array}{c}\text { Arthropod } \\
\text { 5S hemocyanin }\end{array}$ & 29 & & $28^{8}$ \\
\hline $\begin{array}{c}\text { Arthropod } \\
\text { 16S hemocyanin }\end{array}$ & 54 & & $56^{\$}$ \\
\hline $\begin{array}{c}\text { Arthropod } \\
24 S \text { hemocyanin }\end{array}$ & 65.4 & & $64^{3}$ \\
\hline
\end{tabular}

\begin{tabular}{|l|}
\hline MW (kDa) \\
\hline $3000^{f}$ \\
\hline $3200^{f}$ \\
\hline $3000^{\#}$ \\
\hline $250^{\#}$ \\
\hline $250^{\#}$ \\
\hline $75^{\#}$ \\
\hline $450^{\#}$ \\
\hline $900^{\#}$ \\
\hline
\end{tabular}

fValue according to [8]

"Experimental values obtained with techinques different from SAXS

*Radius of gyration of lower molecular weight dissociation products

$\$$ Calculations based on [12] and [13]

\section{Conclusions and perspectives}

In this preliminary work we obtain a survey of some geometrical parameters describing the main subunits of some extracellular dioxygen carriers, summarized in Table 1.

The use of arthropod hemocyanins is a test on the possibilities of SAXS in this field, since the detailed structure of the molecule is known from X-ray crystallography [12]. 
We found interesting the difference between the values of the radius of gyration of the main subunit of Spirographis $s$. chlorocruorin and Octopus $v$. hemocyanin, two species having approximately the same sedimentation coefficient (11S) and molecular weight $(250 \mathrm{kDa})$. The first is known from CTEM to possess a cavity in the inside [6]. The higher radius of gyration of Octopus $v$. hemocyanin suggests instead a more open structure: a ring, made by five equivalent subunits, covalently linked, having $60 \AA$ diameter each, could agree with previus CTEM studies [14]. Elongated structures or "necklaces" made by 7-8 globular units, corresponding to a CTEM model by [15], give a higher estimated radius of gyration $\left(\mathrm{R}_{\mathrm{g}}=78-82 \AA\right)$. It is worth noting that, on one hand, species with similar sedimentation coefficient and $M W$ value give rather different $R_{g}$ and that, on the other hand, as in the case of $16 \mathrm{~S}$ and $24 \mathrm{~S}$ arthropod hemocyanins, similar $R_{g}$ values are obtained for species strongly different in MW. These considerations stress the high sensitivity of SAXS approach to geometrical factors.

The solutions examined are remarkably polydisperse. This obliges us to use complex analysis simulations. Improvements on the preparation of the samples have taken place: on this basis we hope to reach a broader description of the quaternary structure of these proteins, beyond the first references just set.

We thank dr. Patrice Vachette for his experimental help and helpful discussions,

\section{REFERENCES}

[1] PRÉAUX G., GILENS C., Hemocyanins, in Copper Proteins and Copper Enzymes, R. Lontie ed., Vol. II, (CRC Press, Boca Raton, 1984), pag. 159

[2] ANTONINI E., ROSSI FANELLI A., CAPUTO A., Arch. Biochem. Biophys. 97 (1962) 336

[3] BORDAS J., KOCH M.H.J., CLOUT P.N., DAVINGTON E., BOULIN C., GABRIEL A., J. Phys. E. Sci. Instrum. 13 (1980) 938

[4] GLATTER O., KRATKY O., Small Angle X-ray Scattering, (Academic Press, New York, 1982)

[5] RADERMACHER M., WAGENKNECHT T., VERSCHOOR A., FRANK J., J. Microsc. 146 (1987) 113

[6] SANTINI C., CEJKA Z., GHIRETTI MAGALDI A., TOGNON A., A Comparison between Chlorocruorin and Erythrocruorin Structures, in International Congress on Invertebrate Dioxigen Carriers. Abstract Book, (Reprodienst Chemische Laboratoria, Rijkuniversiteit, Groningen, 1992), pag. IV-P08

[7] CEJKA Z., KLEINZ J., SANTINI C., HEGERL R., GHIRETTI MAGALDI A., J. Structur. Biol., 109 (1992) 52

[8] SLITINE F. EL I., TORRIANI I. L., VACHETTE P., Small Angle X-ray scattering study of two annelid extracellular hemoglobins, in Invertebrate Dioxygen Carriers, Gisèle Préaux and René Lontie, eds. (Leuven University Press, Leuven,1990),pag 225

[9] VAN BRUGGEN E.F.J., SCHUTTER W.G., VAN BREEMEN J.F.L., BIJLHOLT M.M.C., WICHERTJES T., Arthropodan and Molluscan Hemocyanins, in Electron Microscopy of Proteins, J.R. Harris ed., Vol 1, (Academic Press, London, 1981), pag. 1

[10] SALVATO B., GHIRETTI MAGALDI A., GHIRETTI F., Biochemistry, 18 (1979) 2731

[11] LA MONACA A., BORGHI E., BARTERI M., BELTRAMINI M., SALVATO B., CONGIUCASTELLANO A., SHAH J.S., Physica Medica, IX (suppl.1 ) (1993) in press

[12] GAYKEMA W.P.J., HOL W.G.J., VEREIJKEN J.M., SOETER N.M., BAK H.J., BEINTEMA J.J., Nature 309 (1984) 23

[13] GAYKEMA W.P.J., VAN SCHAICKE E.J.M., SCHUTTER W.G., HOL W.G.J., Life Chem. Rep., Suppl. 1 (1983) 57

[14] GHIRETTI MAGALDI A., SALVATO B., TOGNON G., MAMMI M., ZANOTTI G., in Invertebrate Oxygen Binding Proteins, J. Lamy and J. Lamy ed., (Marcel Dekker, New York, 1981) 393 [15] WICHERTJES T., GIELENS C., LONCKE P., PRËAUX G., VAN BRUGGEN E.F.J., Comparative Electron Microscopy of the Hemocyanins of Cephalopods Sepia officinalis and Octopus vulgaris, in Invertebrate Dioxygen Carriers, Gisèle Préaux and René Lontie eds. (Leuven University Press, Leuven, 1990), pag. 289 